\title{
Religious Spiritual Assistance for Assisted Residents in the Death Penalty for Drug Cases as a Human Right at the Lapas Nusakambangan
}

\author{
Niken Dwi Astuti Desmawati ${ }^{1}$, Rineke Sara ${ }^{2}$ \\ University of Borobudur, Jl. Pemuda, RT.1/RW.3, Rawamangun, \\ Kec. Pulo Gadung, DKI Jakarta 13220, Indonesia ${ }^{1,2}$ \\ $\left\{\right.$ Nikendwi442@gmail.com ${ }^{1}$, rineke_sara@borobudur.ac.id $\left.{ }^{2}\right\}$
}

\begin{abstract}
Fulfilling the spiritual needs of inmates sentenced to death by drug traffickers is a very necessary need, especially for the mental condition of the inmates. This paper uses an empirical juridical approach, namely research on the study of applicable legal provisions and what happens in reality in society. Although there are many regulations governing death row inmates with the concept of spiritual assistance, there are no specific rules that regulate this to serve as a service guide for these inmates. The study discussed in this paper is related to a religious spiritual approach to strengthen the mentality of the inmates sentenced to death in drug cases.
\end{abstract}

Keywords: Asistance; Spiritual; Drug Cases

\section{Introduction}

Pemberantasan narkoba menjadi tanggung jawab besar dari Negara dalam upayanya untuk melindungi generasi mudanya dari ketergantungan obat-obatan terlarang. Pemerintah melalui Badan Narkotika Nasional (BNN) telah berupaya untuk melakukan pemberantasan peredaran narkoba serta melakukan upaya pencegahan terhadap konsumsi obat-obatan bagi warga negara Indonesia. Karena merupakan suatu kejahatan kemanusiaan yang merugikan orang banyak. Salah satu upaya untuk menimbulkan efek jera adalah penjatuhan vonis hukuman mati kepada pengedar narkoba, baik jaringan regional maupun jaringan internasional. Setidaknya sudah puluhan gembong pengedar narkoba yang mendapatkan vonis hukuman mati dari pengadilan.

Pemberian Hukuman mati bagi kasus tindak pidana peredaran narkotika merupakan salah satu langkah yang tepat dilakukan negara untuk mengeksekusi para pengedar narkoba yang dapat merusak generasi bangsa. Dengan adanya Undang-Undang Nomor 35 Tahun 2009 tentang Narkotika dapat menjerat pengedar/bandar narkoba dengan memberikan hukuman paling berat yaitu hukuman mati. Kementerian Hukum dan HAM sebagai lembaga negara yang diberikan amanah untuk menangani warga binaan pemasyarakatan terutama lembaga pemasyarakatan khusus narkoba dengan vonis hukuman mati di Nusakambangan Kabupaten Cilacap tetap memberikan hak-hak asasi para warga binaan ini diluar hak bebas dari lembaga pemasyarakatan. Hak tersebut antara lain adalah pendampingan spiritual keagamaan bagi terpidana hukuman mati karena kasus narkoba. 


\section{Methodology}

Paper ini menggunakan pendekatan yuridis empiris yaitu penelitian tentang kajian ketentuan hukum yang berlaku dan apa yang terjadi dalam kenyataan di masyarakat. Melihat kontekstualitas dari sisi pendampingan spiritual kepada para narapidana terutama terpidana mati kasus narkotika di Lapas Nusakambangan, Cilacap Jawa Tengah.

\section{Result and Disscusion}

\subsection{Pendampingan Spiritual Keagamaan Terhadap Narapidana}

Pendampingan spiritual keagamaan sejatinya adalah pemenuhan kebutuhan religi terhadap warga negara indonesia atau warga negara asing yang diputus bersalah oleh pengadilan karena melanggar hukum di wilayah Indonesia. Pendampingan spiritual ini merupakan kerjasama Kementerian Hukum dan HAM dengan Kementerian Agama sebagai penyedia pembimbingan rohani.

Ada beberapa fungsi dari pendampingan spiritual ini, antara lain (1) fungsi membimbing (Guiding) yang merupakan bimbingan terhadap konseli dalam memilih atau mengambil sebuah keputusan; (2) fungsi mendamaikan/memperbaiki hubungan (Reconciling) sebagaimana manusia merupakan mahluk sosial yang membutuhkan relasi dengan orang lain; (3) fungsi menopang/menyokong (sustaining) yang ketika konselor diperhadapkan dengan konseli yang mempunyai masalah kritis yang mendalam, sokongan berupa kehadiran dan sapaan yang meneduhkan dan terbuka akan mengurangi penderitaan mereka (Koswanto, 2020); (4) fungsi menyembuhkan, hal ini perlu diberikan kepada konseli yang mengalami tekanan emosi namun tidak pernah diungkapkan dengan kata-kata atau perasanaan seperti menangis dan lainnya, fungsi ini bertujuan untuk mengatasi kerusakan yang dialami seseorang dengan cara memperbaiki orang tersebut menuju keutuhan dan membimbing orang tersebut mencapai keadaan yang lebih maju (Clebsch \& Jaekle, 1994); dan (5) fungsi mengasuh (nurturing), konselor dapat melihat potensi apa saja yang dimiliki oleh konseli sehingga menjadi kekuatan yang dapat digunakan untuk tetap melanjutkan hidup.

Dalam melakukan pendampingan, seorang konselor harus mengetahui tujuan dari pelayanan pendampingan pastoral terhadap orang yang didampinginya tersebut. Beberapa tujuan dari dilakukannya pendampingan pastoral terhadap konseli, yaitu (Safa'ah et al., 2017): Berubah menuju pertumbuhan. Hal ini berarti konselor melakukan pendampingan pastoral secara berkesinambungan dengan tujuan untuk membimbing konseli menjadi agen perubahan, baik untuk dirinya sendiri maupun lingkungan sekitarnya. Mencapai pemahaman diri secara penuh dan utuh. Dengan pendampingan yang dilakukan konselor maka akan menolong konseli dalam memahami dirinya sendiri secara penuh dan utuh. Artinya, konseli dapat memahami akan apa yang menjadi kekuatan dan kelemahan yang ada dalam dirinya. Selain itu, konseli akan mampu melihat setiap kesempatan dan tantangan yang ada sehingga membuat pemahaman dirinya dan semakin percaya diri.

Belajar berkomunikasi yang lebih sehat. Pendampingan yang dilakukan oleh konselor akan menolong konseli dalam menciptakan atau melakukan komunikasi yang baik dan sehat terhadap lingkungannya. Konseli yang memiliki permasalahan hidup, terutama berhubungan dengan sosial, akan sangat sulit untuk berkomunikasi dengan baik dan sehat. Oleh karena itu diperlukan pendampingan untuk melatih konseli tersebut secara formal dan terstruktur. 
Berlatih tingkah laku baru yang lebih sehat. Dengan adanya pendampingan pastoral yang dilakukan, akan menolong konseli dalam mengubah tingkah lakunya yang buruk menjadi lebih sehat. Konselor dapat memberikan arahan dan bimbingan kepada konseli untuk mulai berlatih dan membiasakan tingkah laku yang baru, sehingga dapat diterima oleh lingkungan sekitar. Bagi narapidana bersiap kembali ke lingkungan masyarakat luas, pada umumnya mereka menerima diskriminasi setelah selesai menjalani hukumannya. Masyarakat meyakini bahwa setiap orang yang telah berbuat jahat, maka selamanya ia akan berbuat jahat yang berkepanjangan. Hal ini dapat mengakibatkan narapidana yang sudah bebas dari Lembaga Pemasyarakatan tersebut, tidak mendapatkan tempat dalam berbagai kegiatan sosial dan kembali lagi ke pekerjaan lamanya.

Untuk menghadapi permasalahan tersebut, Lembaga Pemasyarakatan berusaha memberikan pembinaan atau pembimbingan kepada narapidana agar ketika mereka bebas, dapat diterima dalam lingkungan masyarakat. Pembinaan atau pembimbingan yang diberikan berupa pembinaan atau pembimbingan keterampilan. Pembinaan atau pembimbingan keterampilan diberikan dengan tujuan setelah keluar dari Lembaga Pemasyarakatan narapidana dapat menjalani hidupnya dan diterima di tengah-tengah masyarakat dengan harapan tidak melakukan tindakan kriminal (Supriyanto, 2020).

Sebagai tahap eksekusi, lapas mempunyai kegiatan untuk melakukan pembinaan atau pembimbingan terhadap warga binaan narapidana; dimana kegiatan tersebut merupakan bagian akhir dari sistem pemidanaan dalam tata peradilan pidana (Asmarawati, 2019). Pembinaan atau pembimbingan yang dilakukan terhadap narapidana memiliki tujuan. Seperti yang dijelaskan oleh Laurensius Arliman dalam bukunya yang berjudul Hukum dan Kesadaran Masyarakat, pembinaan atau pembimbingan tersebut diberikan agar selama dan selesainya pembinaan atau pembimbingan, para narapidana dapat berhasil memantapkan kembali harga diri dan kepercayaan dirinya serta bersikap optimis akan masa depannya, dapat memperoleh pengetahuan, minimal keterampilan untuk bekal mampu hidup mandiri dan berpartisipasi dalam kegiatan pembangunan nasional, berhasil menjadi manusia yang patuh hukum yang tercermin pada sikap dan perilaku yang tertib, disiplin serta mampu menggalang rasa kesetiakawanan nasional, memiliki jiwa dan semangat pengabdian terhadap bangsa dan negara (Arliman, 2015).

\subsection{Aspek Hak Asasi Manusia Pemenuhan Kebutuhan Spiritual Narapidana}

Hak asasi manusia sudah dimiliki oleh seseorang sejak ia masih dalam kandungan. Hak tersebut melekat dengan kemanusaiaan kita sendiri, yang tanpa hak itu kita mustahil hidup sebagai manusia. Secara umum HAM dipahami sebagai hal yang mutlak sebagai hak-hak dasar ,yang seseorang secara inheren berhak karena dia adalah manusia dan melekat pada semua manusia terlepas dari bangsa, lokasi, bahasa, agama, asal-usul etnis atau status lainnya.

Hak asasi manusia berlaku secara universal. Dasar-dasar HAM yang tertuang dalam UUD 1945 Republik Indonesia seperti yang terdapat dalam pasal 27 ayat 1, pasal 28, pasal 29 ayat 2 , pasal 31 ayat 1 , serta pasal 30 ayat 1 . Ada beberapa pembagian hak asasi manusia yang akan memudahkan kita dalam memahami HAM. Diantaranya hak asasi pribadi, hak asasi politik, hak asasi hukum dan lain sebagainya. Setiap jenis-jenis HAM tentunya memiliki karakteristik yang berbeda-beda.

Kebutuhan spiritual merupakan bagian dari hak asasi pribadi manusia. Meskipun secara hak kebebasan untuk bergerak, bepergian dan berpindah-pindah tidak didapatkan oleh seorang narapidana karena melanggar hukum, namun hak untuk menjalankan agama dan kepercayaan yang diyakininya tetap dapat diberikan. Pemenuhan kebutuhan spiritual ini menjadi aspek 
penting bagi WBP. Aspek tersebut menjadi tugas konselor untuk memenuhinya dengan melihat kebutuhan spiritual yang tepat bagi klien. Konselor dituntut mampu tidak mengenyampingkan kebutuhan spiritual dan selalu berkoordinasi dengan petugas Lapas dalam melihat perkembangan WBP.

\subsection{Asistensi Religi Terpidana Mati Kasus Narkoba}

Asistensi religiusitas narapidana dapat kita lihat dari beberapa dimensi, seperti (1) demensi akidah atau keyakinan; (2) dimensi syariah atau peribadatan; dan (3) dimensi akhlak (Supriyanto, 2020). berbicara aspek dimensi tersebut, dari sisi dimensi akidah para narapidana terpidana kasus narkoba mengakui bahwa perbuatan masa silamnya tersebut menciderai keyakinan yang selama ini mereka pegang teguh.

Sebagai contohnya adalah akidah Islam yang benar dibentuk dengan meyakininya sepenuh hati dan bentuk keyakinan tersebut tercermin dalam perasaan menyesal telah melakukan perbuatan yang buruk yang disertai dengan keinginan untuk merubahnya. Para subjek tersebut mengakui bahwa mereka telah berpasrah diri kepada takdir Tuhan yang telah digariskan.

Dari sisi dimensi syariah. Selain penuturan langsung dari para terpidana hukuman mati, kondisi sosial di dalam Lapas Permisan yang sangat kondusif juga telah membuktikan adanya jalinan yang baik antara sesama warga binaan maupun petugas Lapas. Hal ini dikarenakan Lapas ini merupakan Lapas kelas medium security yang diperuntukkan bagi narapidana yang telah kooperatif dan dapat melakukan sosialisasi dengan baik. Karena lapas medium security memang difokuskan sebagai tempat untuk mengasah keterampilan para warga binaan.

Lagi pula, tujuan diadakan revitalisasi adalah untuk memaksimalkan fungsi pembinaan dalam Lapas itu sendiri. Maka salah satu program yang diadakan adalah dengan melakukan Kerjasama untuk mengadakan program pembinaan kerohanian dengan Kementerian Agama RI dan salah satu Pondok Pesantren di Cilacap.

Program kerjasama yang dimaksud adalah kajian kerohanian atau majlis taklim yang rutin diadakan pada jadwal yang telah disepakati. Program tersebut menjadi salah satu pilihan bagi subjek penelitian untuk menambah pengetahuan keislaman mereka. Oleh karena adanya pengetahuan yang baik, dan berbagai bentukbentuk usaha untuk mengetahui pokok-pokok ajaran Islam, merupakan bentuk usaha terhadap penyucian jiwa (tazkiyah al-nafs) yang pada akhirnya menambah semangat untuk menjalani pokok-pokok ajaran Islam itu sendiri dan menerapkan sifat atau perilaku yang baik dalam kehidupan sosial.

Secara psikologis, narapidana vonis hukuman mati dan narapidana hukuman seumur hidup mengalami perbedaan, karena harapan untuk hidup normal, berkumpul bersama keluarga, dan lain-lain masih terbuka lebar untuk narapidana hukuman semumur hidup. Sedangkan bagi narapidana vonis hukuman mati, harapan untuk itu sangat kecil. Apalagi, narapidana vonis hukuman mati yang penulis wawancarai belum mendapat kejelasan tentang waktu eksekusi mereka, tentu tekanan batin akan semakain terpuruk.

Maka untuk mengatasi gejolak psikologis tersebut, para narapidana vonis hukuman mati terus menerus mencari tujuan hidup serta motivasi untuk tetap dapat menjalani kehidupan dengan baik dan berlapang dada dalam menjalani hukuman. Bagi mereka, kehidupan yang religious menjadi salah satu jalan dalam menenangkan hati dalam menjalani sisa-sisa kehidupan mereka.

Jika melihat perkembangan religiusitas para narapidana vonis hukuman mati di atas, maka kita akan mendapatkan dua faktor penting yang membentuk sikap religius tersebut, yaitu factor internal dan eksternal. Faktor internal yang dimaksud adalah dorongan atau motivasi 
yang timbul dari dalam diri, sedangkan faktor eksternal adalah dorongan atau motivasi yang muncul dari luar dirinya.

\section{Conclusion}

Religiusitas narapidana vonis hukuman mati di Lapas Kelas IIA Permisan Nusakambangan begitu baik. Hal ini terlihat dari keaktifan mereka dalam menjalankan tiga dimensi religiusitas (akidah, syari'ah dan akhlak) dalam kehidupan sehari-hari di dalam Lapas. Perbuatan tersebut muncul karena dorongan dua faktor utama, faktor internal (motivasi dari dalam diri) dan factor eksternal (motivasi dari luar diri). Faktor internal yang mempengaruhi pola religiusitas para narapidana tersebut adalah penyesalan terhadap dosa masa lalu dan ketakutan terhadap kematian.

Dua hal ini memotivasi mereka untuk meningkatkan religiusitas mereka secara berkesinambungan. Sedangkan faktor eksternal yang berpengaruh adalah dukungan dari lingkungan tempat mereka mendekam saat ini, mulai dari fasilitas sarana beribadah yang mendukung, teman-teman yang religius, hingga motivasi yang datang dari keluarga, baik ibu, anak atau istri. Dua faktor ini membentuk pola religiusitas baru dan berbeda dari pola religiusitas mereka sebelumnya ketika berada di luar Lapas.

\section{References}

[1] Aliza, Novia Fetri, Putri Krisdiana, and Yusri Hamzani. 2020. "Religiosity Among Criminals with Death Pinalty: A Study of Nusakambangan Prison.” Dialog 43(2): 24964.

[2] Arliman, Laurensius. 2015. “Konsep Dan Gagasan Pemenuhan Perlindungan Hak Anak Oleh Pemerintah Daerah Di Perbatasan NKRI.” Jurnal Selat 19(2): 341-47.

[3] Asmarawati, Tina. 2019. "Tinjauan Yuridis Terhadap Hukuman Anak Yang Melakukan Tindakan Pidana Kekejaman.”: 161-80.

[4] Clebsch, William A, and Charles R Jaekle. 1994. Pastoral Care in Historical Perspective. Jason Aronson, Incorporated.

[5] Koswanto, Alvin. 2020. "Pendampingan Pastoral Bagi Narapidana Yang Akan Berakhir Masa Tahanan (Tinjauan Aspek Sosial)." VOX DEI: Jurnal Teologi dan Pastoral 1(2): 160-73.

[6] Laurensius Arliman S. 2017. "Komnas HAM Sebagai State Auxiliary Bodies Di Dalam Penegakan Hak Asasi Manusia Di Indonesia.” Jurnal Bina Mulia Hukum 2(40): 54-66.

[7] Mutmainah, Dina. 2020. "Pembinaan Moral Spiritual Bagi Narapidana Di Rumah Tahanan Negara Kelas i Surakarta Tahun 2019/2020 Skripsi."

[8] Safa'ah, Safa'ah, Yuli Nur Khasanah, and Anila Umriana. 2017. "Peranan Bimbingan Konseling Islam Dalam Meningkatkan Moral Narapidana Anak: Studi Pada BAPAS Kelas I Semarang." Sawwa: Jurnal Studi Gender 12(2): 207.

[9] Supriyanto, Eko Eddya. 2020. Eksistensi Nilai-Nilai Pancasila Dalam Kebijakan Ekonomi Indonesia. 1st ed. Malang: Literasi Nusantara.

[10] Supriyanto, Eko Eddya. 2020. "Kontribusi Pendidikan Pesantren Bagi Pendidikan Karakter di Indonesia.” Jurnal Pendidikan NUsantara 1(1): 13-26. 